\title{
DOCUMENTS REGULATING THE VOCATIONAL TRAINING OF MUSIC PERFORMERS IN LITHUANIA AND INTERNATIONALLY: DIRECTIONS, CHARACTERISTICS AND SHORTCOMINGS
}

\author{
Agne Daucianskaite \\ Academy of Education, Vytautas Magnus University, Lithuania \\ Vilma Zydziunaite \\ Academy of Education, Vytautas Magnus University, Lithuania
}

\begin{abstract}
Here is lack of clarity in documentation regarding music performers' training in Lithuania and internationally. Here is lack of information and research-based knowledge regarding strategies, methods, philosophies, competencies and etc., regarding music performers' training. So why it seems for society as "for granted" and that is based on personal talents that are heritage. Also here is lack of documents on requirements for teachers, who prepare the music performers.

The aim of the study is to discuss the issue of music performers' training and education regarding orientations, directions, characteristics and other peculiarities with the focus on a current training and education situation.

The study is based on document analysis.

Documents on musicians' training, which exist in Lithuania and internationally, they lack precision, clarity, specificity in terms of specializations, instruments, levels of achievement( $s$ ), specifications for performance assessment, and levels of professionalism achieved. Most of the documents are generic, politicized, and their content is deliberative about how it must be, what shows that documents do not rely on empirical research evidence within the practical reality, and are not oriented to realistic ways, how to achieve the specific results that reflect the quality of musical performance.
\end{abstract}

Keywords: document analysis; international context; Lithuania; vocational training of music performers.

\section{Introduction}

Vocational music training is a consistent and long pedagogical process. Becoming a professional musician starts noticeably in childhood, when the child plays a musical instrument that becomes more and more interesting. Later, naturally, it becomes a form of leisure, and then, the students themselves decide to pursue a professional music career (Huhtanen, 2008). According to A. Watson 
(2010), vocational music training occupies a major part of a musician's career because professional development takes place throughout life.

There are important factors involved in preparing the professional musicians in musical training, then the attention must be paid to the following factors: the professional skills of the teacher in a particular music specialization, the teacher's ability to take into account the learner's abilities, abundance of educational techniques, educational environment, quality of concerts, variety of competitions and masterclasses, ongoing engagement into educational and self-improvement process, performance of new musical productions, stage experiences, collaboration with parents (Lepherd, 2000; Gabnyte, 2011; Burt-Perkins, 2008; Constable, 2005; Huhtanen, 2008, 2010; Johnsson \& Hager, 2006; Triantafyllaki, 2010; Weller, 2004, 2008). While it seems obvious that vocational training of musicians is a consistent, systematic and continuous process, there is a lack of systematic and specific research evidence-based information on how a professional musician is trained, what kind of the educational relationship is implemented in collaboration between learner and teacher, how learning and teaching are carried out, what methods are used to train professional musicians and how the communication between the teacher and the learner is formed, what kind of educational atmosphere prevails during the classes, what technical principles are used by the teacher and so on. Thus, there is a lack of researchbased information on these issues regarding vocational training of musicians both nationally and internationally.

There are a lot of discussions among music educators in Lithuania and internationally about training of professional musicians. Therefore, seminars and masterclasses are organized in which educators share their experiences, knowledge and skills. However, there is very little research in Lithuania (Rinkevičius, 2002; Bukantaitė \& Gerulis, 2012) and internationally on vocational training of musicians (Burt-Perkins, 2008; Constable, 2005; Huhtanen, 2010; Johnsson \& Hager, 2006; Weller, 2008). The educational documents refer to the popular music performer standard, the traditional music performer standard, the professional module and the curriculum for gifted and talented children, the specialized learning standard program that many professional musicians draw on specialists in various music schools, colleges, conservatoires or universities of arts.

The aim of the study is to discuss the issue of music performers' training and education regarding orientations, directions, characteristics and other peculiarities with the focus on a current training and education situation. The study is based on document analysis. 


\section{Documents regulating the training of music performers in Lithuania: strengths and weaknesses}

Analyzing the training of music performers in the Lithuanian context the following documents (Table 1) are found with the focus on traditional folk musician training (Tradicinès liaudies muzikos atlikejjo rengimo standartas, 2007), popular music performer training (Populiarios muzikos atlikejjo rengimo standartas, 2007) and specialized music education programs (Specializuoto ugdymo krypties programu (pradinio, pagrindinio ir vidurinio ugdymo kartu su muzikos ugdymu programų) muzikos ugdymo dalis, 2013).

Table 1 Strengths and weaknesses of documents regarding music performer training: The

\section{Lithuanian context}

\begin{tabular}{|c|c|c|}
\hline Document title & Strengths & Weaknesses \\
\hline $\begin{array}{l}\text { Traditional folk } \\
\text { music performer } \\
\text { training standard } \\
(2007)\end{array}$ & $\begin{array}{l}\text { Areas of activity are systematically } \\
\text { described (traditional singing and music in } \\
\text { solo and ensemble; popularization of } \\
\text { traditional folk music; creative } \\
\text { interpretation of traditional folk music). } \\
\text { The standard provides a finite } \\
\text { characterization of the competences to be } \\
\text { acquired and their boundaries. } \\
\text { The purpose of the standard ensures the } \\
\text { areas of learning covered by the standard } \\
\text { and the ways in which they are taught. }\end{array}$ & $\begin{array}{l}\text { The standard is designed to provide } \\
\text { higher non-university education. } \\
\text { The document does not detail the } \\
\text { characteristics of the techniques and } \\
\text { methods. } \\
\text { This document is for older learners. } \\
\text { The standard is intended for those } \\
\text { who already achieved the certain } \\
\text { level of a musical education. }\end{array}$ \\
\hline $\begin{array}{l}\text { Popular music } \\
\text { performer } \\
\text { training standard } \\
(2007)\end{array}$ & $\begin{array}{l}\text { The document clearly provides a finite and } \\
\text { representative list of competences to be } \\
\text { acquired. } \\
\text { The standard specifies learning objectives. } \\
\text { The standard specifies the areas of activity } \\
\text { in which the performer will be able to } \\
\text { realize her / himself after the standard has } \\
\text { been completed. } \\
\text { The purpose of the standard is focused on } \\
\text { the areas of learning it covers and specific } \\
\text { ways of teaching. }\end{array}$ & $\begin{array}{l}\text { The standard is designed to provide } \\
\text { higher non-university education. } \\
\text { The standard does not include } \\
\text { technics and learning methods. } \\
\text { This document is for older learners. } \\
\text { The standard is intended for those } \\
\text { who already achieved the certain } \\
\text { level of a musical education. }\end{array}$ \\
\hline
\end{tabular}


Daucianskaite \& Zydziunaite, 2020. Documents Regulating the Vocational Training of Music Performers in Lithuania and Internationally: Directions, Characteristics and Shortcomings

\begin{tabular}{|c|c|c|}
\hline $\begin{array}{l}\text { Music education } \\
\text { part of } \\
\text { specialization } \\
\text { programs } \\
\text { (primary, basic } \\
\text { and secondary } \\
\text { education } \\
\text { combined with } \\
\text { music education) } \\
\text { (2013) }\end{array}$ & $\begin{array}{l}\text { There are clear objectives for each stage of } \\
\text { the education. } \\
\text { The document clearly states the most } \\
\text { important criteria for the development of } \\
\text { each specialized musical subject (artist } \\
\text { expression, knowledge and understanding, } \\
\text { skills, interpretation of musical works, } \\
\text { musical expression of a performer in social } \\
\text { culture). } \\
\text { The document is aimed at primary, } \\
\text { secondary and basic education. } \\
\text { The document identifies programme } \\
\text { requirements for all specializations. } \\
\text { The document outlines the basic training } \\
\text { models and characteristics of artist } \\
\text { manifestations / exhibition. }\end{array}$ & $\begin{array}{l}\text { The document is generic: although } \\
\text { specific to all stages of schooling, it } \\
\text { does not provide specific information } \\
\text { for each level. } \\
\text { The information in this document is } \\
\text { summative: the document analyzes } \\
\text { all musical specializations without } \\
\text { any specificity. } \\
\text { The document is written for students } \\
\text { with different musical abilities. } \\
\text { Schools are given full responsibility } \\
\text { for curriculum development based on } \\
\text { the needs and abilities of students } \\
\text { (there is no mentioned the need for } \\
\text { the system, which must be approved } \\
\text { in documentation and then } \\
\text { implemented). }\end{array}$ \\
\hline
\end{tabular}

All analyzed documents refer to the training of a music performer. The aspects analyzed in the standard of popular and traditional music are aimed at the students who already achieved a certain level of a musical education.

However, the specialized education program is aimed at children of all abilities. It is noteworthy that documents set out the goals and objectives that ensure the execution of the programs and the organization of the various subjects of music education. There is a lack of documentation defining the development of teachers to train professional music artists. There is also a lack of documentation and standards related to the training of professional musicians in higher education institutions (academies, universities). There is a need for documentation on the music education system, and then it is shaped by the schools itself and they provide music education at different levels of education, adapting to the requirements and needs of the country's education system.

\section{Documents regulating the training of music performers in the international arena: strengths and weaknesses}

Analyzing the training of musicians in an international context is dominated by documents on the following aspects (Table 2): Educating professional musicians in a global context (2012), Relevance and reform in the education of professional musicians (2014), Recommendations to the European Union about the role of music education and training in the new EU programme for culture (2004), Preparing young musicians for professional training: what does scientific research tell us? (2017), Music standards for teachers of students 3 - 18+ (2001). 
Table 2 Strengths and weaknesses in the international documentation of music performer training

\begin{tabular}{|c|c|c|}
\hline Document title & Strengths & Weaknesses \\
\hline $\begin{array}{l}\text { Educating professional } \\
\text { musicians in a global } \\
\text { context (2012) }\end{array}$ & $\begin{array}{l}\text { The document systematizes scientific } \\
\text { evidence-based information across } \\
\text { professional music education topics: music } \\
\text { careers, musicianship education for a } \\
\text { diverse and sustainable career, professional } \\
\text { musician identities for individuals and } \\
\text { institutions, physical and psychological } \\
\text { wellbeing of musicians, music education } \\
\text { program, technology in music education } \\
\text { and professional musician's life. } \\
\text { The information contained in the document } \\
\text { is specific and clear. } \\
\text { The content of the document contributes to } \\
\text { the recognition of musicians in education. } \\
\text { The document describes teaching and } \\
\text { learning methods for teachers working with } \\
\text { students. }\end{array}$ & $\begin{array}{l}\text { The document does not speak } \\
\text { about the technics in } \\
\text { education of professional } \\
\text { musicians. } \\
\text { The document does not } \\
\text { contain generalizations that } \\
\text { focus on the fundamental } \\
\text { directions, values, features of } \\
\text { music education. }\end{array}$ \\
\hline $\begin{array}{l}\text { Relevance and reform in } \\
\text { the education of } \\
\text { professional musicians } \\
(2014)\end{array}$ & $\begin{array}{l}\text { Systematically collected scholarly articles } \\
\text { from around the world on institutional } \\
\text { cultures and leadership in relation to music } \\
\text { education and performance, curriculum } \\
\text { updates, creative musical teaching } \\
\text { practices, technology support in musicians' } \\
\text { training, and global musical perspectives. } \\
\text { The document provides the most important } \\
\text { criteria for the development of each } \\
\text { specialized musical subject. }\end{array}$ & $\begin{array}{l}\text { There are no systematic, } \\
\text { specific conclusions about the } \\
\text { musical specialization, theme, } \\
\text { and direction of musician } \\
\text { education. } \\
\text { The document is universal, } \\
\text { but it does not contain any } \\
\text { software requirements or } \\
\text { provisions for training a } \\
\text { professional music artist. }\end{array}$ \\
\hline $\begin{array}{l}\text { Recommendations to the } \\
\text { European Union about } \\
\text { the role of music } \\
\text { education and training in } \\
\text { the new EU programme } \\
\text { for culture (2004) }\end{array}$ & $\begin{array}{l}\text { The document reveals improvements in } \\
\text { music education programs. } \\
\text { The document encourages cooperation } \\
\text { between music organizations in Europe, } \\
\text { both formal and informal. } \\
\text { The document encourages the collection of } \\
\text { information on music teacher education } \\
\text { and training. } \\
\text { The document introduces the profession of } \\
\text { musician, which combines several } \\
\text { activities. }\end{array}$ & $\begin{array}{l}\text { The document is political in } \\
\text { nature and lacks scientific } \\
\text { evidence. } \\
\text { The document focuses on the } \\
\text { general principles, trends, and } \\
\text { values of teacher education, } \\
\text { with little specification of the } \\
\text { specifics, specializations, } \\
\text { mission, and values of a } \\
\text { music teacher. } \\
\text { The document lacks } \\
\text { specifications for the } \\
\text { musician profession in terms } \\
\text { of criteria and indicators, as } \\
\text { well as quality indicators and } \\
\text { distinguishing characteristics } \\
\text { compared to other arts } \\
\text { professions. }\end{array}$ \\
\hline
\end{tabular}


Daucianskaite \& Zydziunaite, 2020. Documents Regulating the Vocational Training of Music Performers in Lithuania and Internationally: Directions, Characteristics and Shortcomings

\begin{tabular}{|c|c|c|}
\hline $\begin{array}{l}\text { Preparing young } \\
\text { musicians for } \\
\text { professional training: } \\
\text { what does scientific } \\
\text { research tell us? (2017) }\end{array}$ & $\begin{array}{l}\text { The document was created by a specific } \\
\text { group of experts involved in a specific } \\
\text { project. } \\
\text { The paper presents philosophical theories } \\
\text { relevant to early music education. } \\
\text { The document provides analysis-based } \\
\text { information about thinking in music } \\
\text { education. } \\
\text { The document provides the attitudes } \\
\text { toward training of professional music } \\
\text { artists in an early age. } \\
\text { The document discusses international } \\
\text { trends and developments in professional } \\
\text { music education. }\end{array}$ & $\begin{array}{l}\text { The document consists of } \\
\text { material that is based on } \\
\text { theoretical research and } \\
\text { philosophical considerations, } \\
\text { but does not rely on empirical } \\
\text { evidence that explores current } \\
\text { practices in music education } \\
\text { and musicians' training. }\end{array}$ \\
\hline $\begin{array}{l}\text { Music Standards for } \\
\text { teachers of students } 3- \\
18+(2001)\end{array}$ & $\begin{array}{l}\text { The document describes an experienced } \\
\text { music teacher. } \\
\text { The document tells the music teacher how } \\
\text { to systematically get to know the child. } \\
\text { The document provides assessment } \\
\text { systems that could be applied to the work } \\
\text { of a good music educator. } \\
\text { The document outlines how a music } \\
\text { teacher should organize music learning } \\
\text { activities in a social culture. } \\
\text { The document sets out how to keep in touch } \\
\text { with parents, colleagues in the musical } \\
\text { education of the child. }\end{array}$ & $\begin{array}{l}\text { The document is } \\
\text { characterized by general } \\
\text { tendencies, statements, but } \\
\text { lacks precision and } \\
\text { specificity. }\end{array}$ \\
\hline
\end{tabular}

Documents on training of musicians and music teacher contain both empirical evidence and theoretical, and philosophical considerations, but are lacking specification, concreteness, clarity, and accuracy. While not neglecting the importance of diverse considerations, the lack of documentation about music performers and the exceptionality of music teacher training remains an important documentary shortage. These documents provide information about the expectations of what a music teacher should be like when training professional musicians, what is professional music education, but these documents do not specify goals, competencies according to musical specializations, level of achievement, and so on. Documents often mention collaboration between European countries and share experiences on how to train a professional music artist.

\section{Discussion}

Similarities and differences between documents regulating the training of music performers in Lithuania and internationally: directions and characteristics. After analyzing the documents, it can be stated that the documents 
intended for the training of music performers in Lithuania and internationally set out general goals, tasks and criteria for the learners, emphasizing what and how they should achieve in music education. However, in Lithuania, here is not document or scientific articles intended to describe and discuss professional music performers' training, professional development or competence improvement. All documents in Lithuania regarding musicians' training and professional music performing are provided in a general, non-specific way, i. e. for both amateur and professional music performers. There is no specific standards in Lithuania for training of musical performers and music teachers. Such kind of a document is important to have because there is an expectation of what it will contain information on how to train professional music artists and music teachers. Internationally, a standard for music teachers' activities with students has been developed, and scientific articles on professional music education have been found. However, international documents do not contain specific programmatic requirements to educate music performers.

The need to improve the documents regulating the training of music performers in Lithuania and internationally. Documentary analysis suggests that there is documentation on the training of music performers, but it must be improved. There is a lack of documentation on the training of professional musicians for music teachers, a lack of standards for the training of professional musicians at university level, and a lack of documentation on the qualifications and requirements for teaching staff in higher education. Uncertainties remain as to the quality of training of professional musicians. It makes sense in the documents to pay more attention to the music teacher at school and college level as a specialist in musical teaching work. Documents must play not only the a political role, but it also has to rely on evidence from empirical research, based on practical studies in regard to training of musicians. It makes sense to specify the documentation to target amateur and professional music artists, as the documentation is currently generic.

Here are a lot of fragmented documents regarding expectations on music performers' education and training, also the local (institutional) documents are dominating still. Thus here is lack of information and research-based knowledge regarding strategies, methods, philosophies, competencies and etc., regarding music performers' training. So why it seems for society as "for granted" and that is based on personal talents that are heritage. Also here is lack of documents on requirements for teachers, who prepare the music performers.

\section{Conclusions}

Documents on musicians' training, which exist in Lithuania and internationally, they lack precision, clarity, specificity in terms of specializations, 
Daucianskaite \& Zydziunaite, 2020. Documents Regulating the Vocational Training of Music Performers in Lithuania and Internationally: Directions, Characteristics and Shortcomings

instruments, levels of achievement(s), specifications for performance assessment, and levels of professionalism achieved. Most of the documents are generic, politicized, and their content is deliberative about how it must be, what shows that documents do not rely on empirical research evidence within the practical reality, and are not oriented to realistic ways, how to achieve the specific results that reflect the quality of musical performance. There is, at least, a need for a document that systematically distinguishes criteria and indicators for the professional musician / performer and their training. Such a document would be of interest to music professionals, teachers and non-musicians alike.

Here is lack of documents on training of workforce of professional "portfolio" musicians. As professional practitioner, a musician must not only excel as a performer, but also as a teacher, leader and creative collaborator across a range of styles and genres. Music performers should learn how to teach from the outset of their training, how to pass on their knowledge and engage with musical discourse on as many levels as possible. And the formal documents must create premises for professional music performers to be acquainted with requirements for quality of performance and training, and education of musicians.

\section{References}

Bukantaitè, D., \& Gerulis, S. (2012). Muzikinio ugdymo dimensijos socialinių ir humanitarinių mokslų sankirtoje. In Vytauto Didžiojo universiteto mokslo klasteriai. Part II.

(pp. 237-244). Kaunas: Vytautas Magnus University Publishing.

Burt-Perkins, R. (2008). Students at a UK conservatoire of music: working towards a 'diverse employment portfolio'? In D. Bennett, \& M. Hannan (Eds.) Inside Outside Downside Up: Conservatoire Training and Musicians' Work. (pp. 49-60). Perth: Black Swan Press.

Constable, J. (2005). The hat collector? No, it's the multi-skilled arts administrator. Orchestral Outlook, 12(2), 6-12.

Educating Professional Musicians in a Global Context (2012). Proceedings of the 19th International Seminar of the Commission for the Education of the Professional Musician (CEPROM) International Society for Music Education. Philippos Nakas Conservatory, Athens, Greece: International Society for Music Education. Retrieved from https://www.isme.org/sites/default/files/documents/proceedings/2012\%2BCEPROM\%2 BProceedings.pdf

Gabnytė, G. (2011). Edukacinių pokyčių vaikų muzikos mokykloje galimybės laisvojo ugdymo paradigmos kontekste. Jaunujų mokslininku darbai, 4(33), 21-28.

Huhtanen, K. (2008). Constructing a conscious identity in instrumental teacher training. In D. Bennett, \& M. Hannan (Eds.). Inside Outside Downside Up: Conservatoire Training And Musicians' Work. (pp. 1-10). Perth: Black Swan Press.

Huhtanen, K. (2010). Towards creative entrepreneurship. In M. Hannan (Ed.). The Musician In Creative And Education Spaces Of The 21st Century. Draft Proceedings of the 18th International Seminar of Commission for the Education of the Professional Musician, ISME. (pp. 65-68). Retrieved from https://www.researchgate.net/profile/Dawn_Bennett/ publication/45581069_Inside_outside_downside_up_conservatoire_training_and_music 
ians'_work/links/59dea94c0f7e9bcfab240d61/Inside-outside-downside-upconservatoire-training-and-musicians-work.pdf\#page $=70$

Johnsson, M., \& Hager, P. (2006). Navigating The Wilderness Of Becoming Professional. Retrieved from https://www.researchgate.net/publication/242156374_Navigating_ the_wilderness_of_becoming_professional

Lepherd, L. (2000). Training for a professional instrumental and vocal teacher - at a distance. The Education of the Professional Musician, 2(3), 81-92.

Music Standards For Teachers Of Students 3-18+ (2001). Arlington, VA: National Board for Professional Teaching Standards. Retrieved from https://www.nbpts.org/wpcontent/uploads/ECYA-MUSIC.pdf

Populiarios muzikos atlikejjo rengimo standartas. (2007). Vilnius: Lietuvos respublikos švietimo ir mokslo ministerija ir Lietuvos Respublikos socialinès apsaugos ir darbo ministerija. Retrieved from

https://webcache.googleusercontent.com/search?q=cache:f1C2r6T1PnkJ:https://eseimas.lrs.lt/rs/lasupplement/TAD/TAIS.306199/b45ef28032f011e6a222b0cd86c2adfc/ format/ISO_PDF/+\&cd=4\&hl=lt\&ct=clnk\&gl=lt

Preparing Young Musicians For Professional Training: What Does Scientific Research Tells Us? (2017). Dutch National Profile for Music. Amsterdam: Netwerk Muziek. Retrieved from https://www.vereniginghogescholen.nl/system/profiles/documents/000/000/225/ original/muziek.op.2018.eng.pdf?1520590049

Recommendations To The European Union About The Role Of music Education And Training In The New EU Programme For Culture. (2004). Brussels: European Forum for Music Education and Training. Retrieved from https://www.emc-imc.org/fileadmin/ user_upload/EFMET/EFMET_Recommendations_English.pdf

Relevance And Reform In The Education Of Professional Musicians. (2014). Proceedings of the 20th International Seminar of the ISME Commission on the Education of the Professional Musicians. Belo Horizonte, Brazil: International Society for Music Education. Retrieved from https://www.isme.org/sites/default/files/documents/proceedi ngs/2014-CEPROM-Proceedings.pdf

Rinkevičius, Z. (2002). Muzikinis auklejjimas: sąvokos aktualizavimas. Tiltai, 1, 115-121. Retrieved from https://etalpykla.lituanistikadb.lt/object/LT-LDB-0001:J.04 2002 1367178765013/J.04 2002 1367178765013.pdf

Specializuoto ugdymo krypties programu (pradinio, pagrindinio ir vidurinio ugdymo kartu su muzikos ugdymu programu) muzikos ugdymo dalis. (2013). Vilnius: Lietuvos Respublikos Švietimo, mokslo ir sporto ministerija. Retrieved from https://www.smm.lt/uploads/documents/svietimas/ugdymo-programos/1-

$12 \% 20 \mathrm{kl} \% 20 \% 20$ muzikos\%20ugdymo\%20dalies\%20\%20programa.pdf

Tradicinès liaudies muzikos atlikejo rengimo standartas. (2007). Retrieved from https://webcache.googleusercontent.com/search?q=cache:Lm1FfFrfC6sJ:https://eseimas.lrs.lt/rs/lasupplement/TAD/TAIS.306199/b4496eb032f011e6a222b0cd86c2adfc/ $+\& \mathrm{~cd}=2 \& \mathrm{hl}=\mathrm{lt} \& \mathrm{ct}=\mathrm{clnk} \& \mathrm{gl}=\mathrm{lt}$

Triantafyllaki, A. (2010). Advanced music-training institutions as landscapes for performance teachers' professional career development: the case of Greece. In Proceedings Of The 18th International Seminar of Commission For The Education Of The Professional Musician (CEPROM) The Musician in Creative and Education Spaces of the 21st Century. Australia: International Society for Music Education (ISME). (pp. 86-91). 
Daucianskaite \& Zydziunaite, 2020. Documents Regulating the Vocational Training of Music

Performers in Lithuania and Internationally: Directions, Characteristics and Shortcomings

Watson, A. (2010). Musicians as instrumental music teachers: issues from an Australian perspective. International Journal of Music Education 28(2), 193-203. Doi: $10.1177 / 0255761410362939$

Weller, J. (2004). The whole musician: journey to authentic vocation. In O. Musumeci (Ed.), Preparing Musicians For New Sound Worlds. (pp. 245-256). ISME: Nedlands.

Weller, J. (2008). Creating a life in music: theory to praxis. In D. Bennett, \& M. Hannan (Eds.) New Models for Educating Professional Musicians in the Twenty-First Century (174-184). Retrieved from https://www.isme.org/sites/default/files/documents/proceedings/2006\%20CEPROM\%2 OProceedings.pdf 